\title{
Obituary
}

\section{DAVID FRANCIS VAN ZWANENBERG, DM, DCH, DPH}

(1922-1991)

Born into a Dutch family with business interests in Britain, and later domiciled here, David was born in London on 16 March 1922. His later education was at Trinity College, Oxford and his professional training at St. Bartholomew's Hospital, London. He graduated BM, B.Ch in 1945 . After time in the RAMC, he was able to expand his interests, acknowledged by the Diploma in Child Health and by the Diploma in Public Health, and in 1948 he was appointed Medical Superintendent of the Isolation Hospital in Ipswich, Suffolk (later known as St. Helen's Hospital.)

There he established himself as an administrator as well as a clinician, devoted to his patients and always helpful to colleagues in practice. In 1959, he proceeded to the Doctorate, with a thesis on tuberculin testing in pulmonary tuberculosis, a disease with which he was much concerned, particularly in the then practised use of artificial pneumothorax. He was later appointed, in 1963, Consultant Physician in Infectious Diseases and Chest Medicine.

His early interest in general history merged with medicine to turn him into a eminent historian of medicine. For this, he will be remembered, perhaps most for his paper on the last outbreak of bubonic plague in England, 1906-1918, published in Medical History in 1970.

He was essentially a local historian of immense patience and persistence in exploring provincial records. Twenty years of research produced some 3,000 biographical notes on practitioners of medicine born or working in the County of Suffolk 1200-1900, a most valuable archive yet to be analysed and published, in the keeping of the Suffolk Record Office. Another project was a history of disease in East Anglia, on which he could have written with unassailable authority.

As it turned out, all these plans were frustrated by a long and distressing illness. He died, aged sixty-nine, on 15 July 1991 . He was helpful and generous to all students, whether of history or of medicine, or of the conjoined disciplines. For those who knew him, there remains the memory of great scholarship, broad learning and perceptive intelligence, all tragically cut short.

J. W. DICKSON 